\title{
Screening of blue crab (Portunus pelagicus L.) eyestalk extracts for growth inhibition of Pectobacterium carotovorum subsp. carotovorum (Hauber et al. 1998) (Erwinia carotovora) Jones (Holland) and Ralstonia solanacearum (Yabuuchi et al. 1995) (Pseudomonas solanacearum) E. F. Smith
}

\author{
Julissah C. Evangelio and Bernardita P. Germano \\ Institute of Tropical Ecology-Marine Laboratory and Department of Biological \\ Sciences, Leyte State University. Baybay, Leyte, Philippines
}

\section{ABSTRACT}

Evangelio, J. C. and B P. Germano. 2006. Screening of blue crab (Portunus pelagicus L.) eyestalk extracts for growth inhibition of Pectobacterium carotovorum subsp. carotovorum (Hauber et al. 1998) (Erwinia carotovora) Jones (Holland) and Ralstonia solanacearum (Yabuuchi et al. 1995) (Pseudomonas solanacearum) E. F. Smith. Ann. Trop. Res. 28(2):92-110.

Crustacean eyestalks are known to contain neurosecretory hormones that inhibit molting, growth and gonadal development. Along this framework, this study was conducted to: screen crude eyestalk extracts from the blue crab Portumas pelagicus for possible growth inhibition on two bacterial pathogens Ralstonia solanacearm and Pectobacterium carotovorum subsp. carotovorum, and determine effective concentrations of the crude extract against the pathogens. The screening was done through bioassay using the top agar inoculation technique with $70 \%$ ethanol as the extracting solvent and streptomycin as the positive control. Different concentrations of blue crab extract and streptomycin were obtained using serial dilution.

Results showed inhibitory effects of the blue crab eyestalk extracts against the

Keywords: Portunus pelagicus eyestalks, growth inhibiting ho mone, Psewdome carotovorum subsp. carotovorum, Ralstonia solanacearum

Correspondence. J.C. Evangelio Present Address: Institute of Tropical h. wougy-Marrec Laboratory, Leyte State University, Baybay Leyte, Philippines. Telefas $(153,3, ? 26$. 
two pathogens $R$. solanacearum and $P$. carotovorum at bacterial populations ranging from $4.63 \times 10^{6}-5.70 \times 10^{6}$ for the former and $5.20 \times 10^{6}-5.95 \times 10^{6}$ for the latter. However, inhibitory effects of the eyestalk extracts were apparently lower than that of streptomycin and seem to be comparable to growth inhibition at lower concentrations of streptomycin. Moreover, the mixed molt and reproductive stages of the eyestalk source crabs may have diluted the concentrations of eyestalk hormones. Among the two pathogens, $P$. carotovorum appeared more responsive to the different concentrations of eyestalk extracts. It showed greater inhibition by the extract at the maximum concentration of $44.5 \mathrm{mg} \mathrm{mL}^{-1}$ and had a lower minimum inhibitory concentration (MIC) of $1.39 \mathrm{mg} \mathrm{mL}^{-1}$.

Results further suggest that blue crab eyestalk extracts can be used as a possible control agent against the growth of bacterial pathogens $P$. carotovorum and $R$. solanacearum. However, further verification of the study should be done to determine eyestalk extract effect at higher pathogen populations.

\section{INTRODUCTION}

Both vertebrates and invertebrates have special cells in the central nervous system that produce neurohormones. These neurosecretory cells combine the best features of the nervous and endocrine system. The neurohypophysis of the vertebrates is a good example of a neurohemal organ. Similar to the neurohypophysis in the vertebrates, invertebrates such as crustaceans (crabs, lobsters, shrimps, etc.) have the sinus gland, found in the eyestalk. Cells of the ' $x$ ' organ, also found in the eyestalk, produce and release neurohormones to the sinus gland, which stores and releases the hormones into the hemolymph for metabolic and behavioral activities.

The presence of neurosecretory hormones that inhibit molting and growth in the eyestalks of crustaceans is well-documented (Kleinholz, 1976; Bliss, 1966; Passano 1960; Skinner, 1984). Factors influencing hydromineral regulation, gonad inhibition, cardiac activity, respiratory rates and lipid metabolism are also found in crustacean eyestalks (Kleinholz, 1976; Chang, 1989). The eyestalk removal practice in aquaculture to accelerate molting, also enhances growth and gonadal development (Germano, 1994). The mechanisms of molting and growth inhibition include inhibition of incorporation of radiolabeled precursors into macromolecules possibly due to depression of RNA and protein synthesis (Chang, 1989).

In view of the growth inhibitory effects of neurosecretory hormones in crustacean eyestalks, the possible use of crude extracts of crustacean eyestalks 
for arresting growth in cancerous cells was envisioned. However, since cancerous cells are not easy to culture and maintain, it was thought that investigations must first be done on simpler procaryotic cells particularly those bacterial pathogens. Investigations on a number of crustaceans have shown the efficacy of eyestalk ablation in accelerating molting, enhancing growth and gonadal development. However, there is no information on the application of hormones from eyestalk extracts of Portunus pelagicus to inhibit the growth of bacterial pathogens particularly Pectobacterium carotovorum subsp. carotovorum (Hauber et al. 1998) and Ralstonia solanacearum (Yabuuchi et al. 1995) which cause wilting and soft rots in a number of crops. Furthermore, this particular species of crustacean is locally abundant and thus, practical to use on a larger scale. This investigation may provide an environment-friendly alternative method of biological control of bacterial plant diseases for use in agriculture. Moreover, positive results from this investigation may pave the way for enhanced profitability of the blue crab processing industry which at present regards eyestalks as waste products.

\section{MATERIALS AND METHODS}

\section{Sample preparation}

The blue crab Portunus pelagicus (Fig. 1) was used as source of eyestalk extracts. For ease in handling, fresh dead specimens were used in the experiment. These were obtained from Phillips Seafood Inc. and OCSI (Orient Cold Storage Incorporated) Factory in Catbalogan, Samar (Fig. 2) since the supply from Baybay market was not enough for the experiment. The eyestalks that came from approximately 100 crabs were placed in an ice bucket to minimize deterioration.

\section{Preparation of crude extracts}

Eyestalk extracts were obtained by cutting the eyestalk at the base. These were homogenized in $70 \%$ ethanol (Kleinholz, 1976) for the preparation of different concentrations. A centrifuge was used to separate the extracts from the eyestalk shell and decantation followed. Crude extracts from the eyestalk 


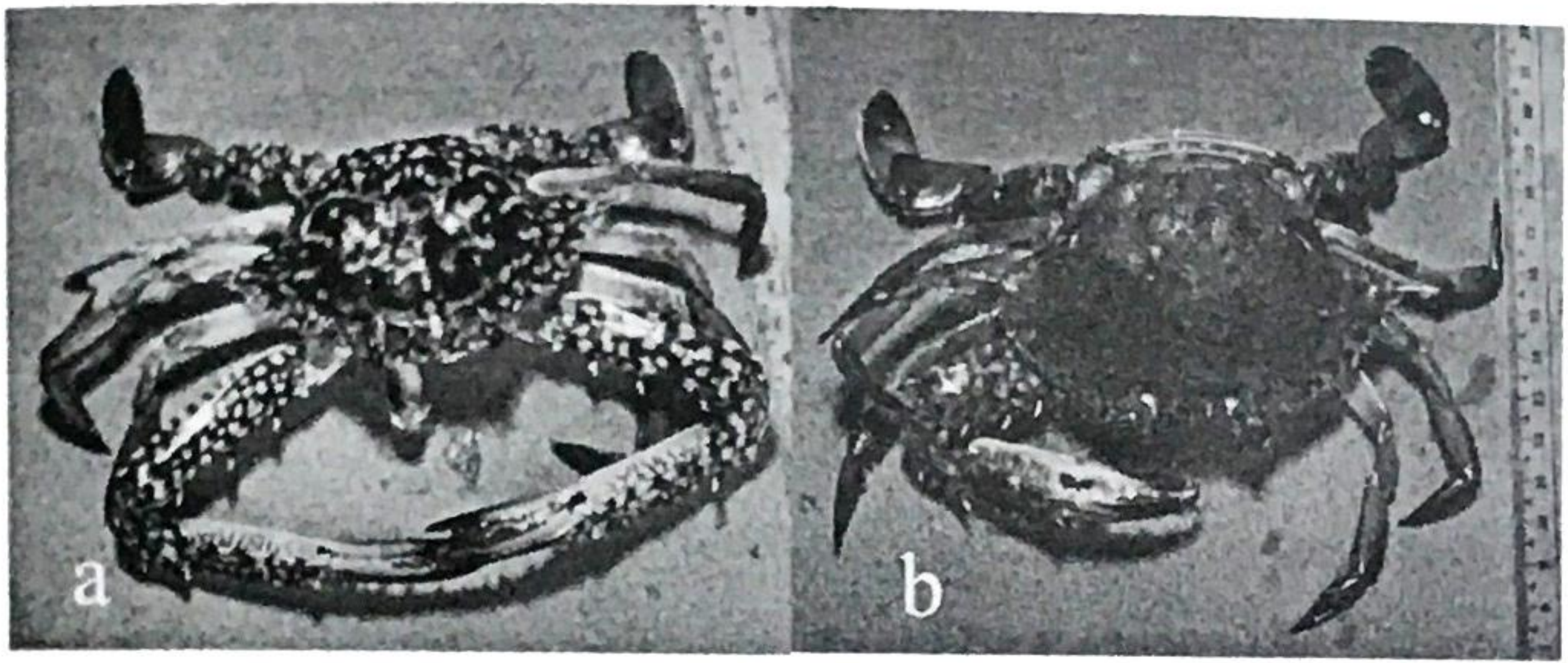

Figure 1. Male (a) and female (b) blue crabs Portunus pelagicus L. (photo from AFMAInvertebrate Project)

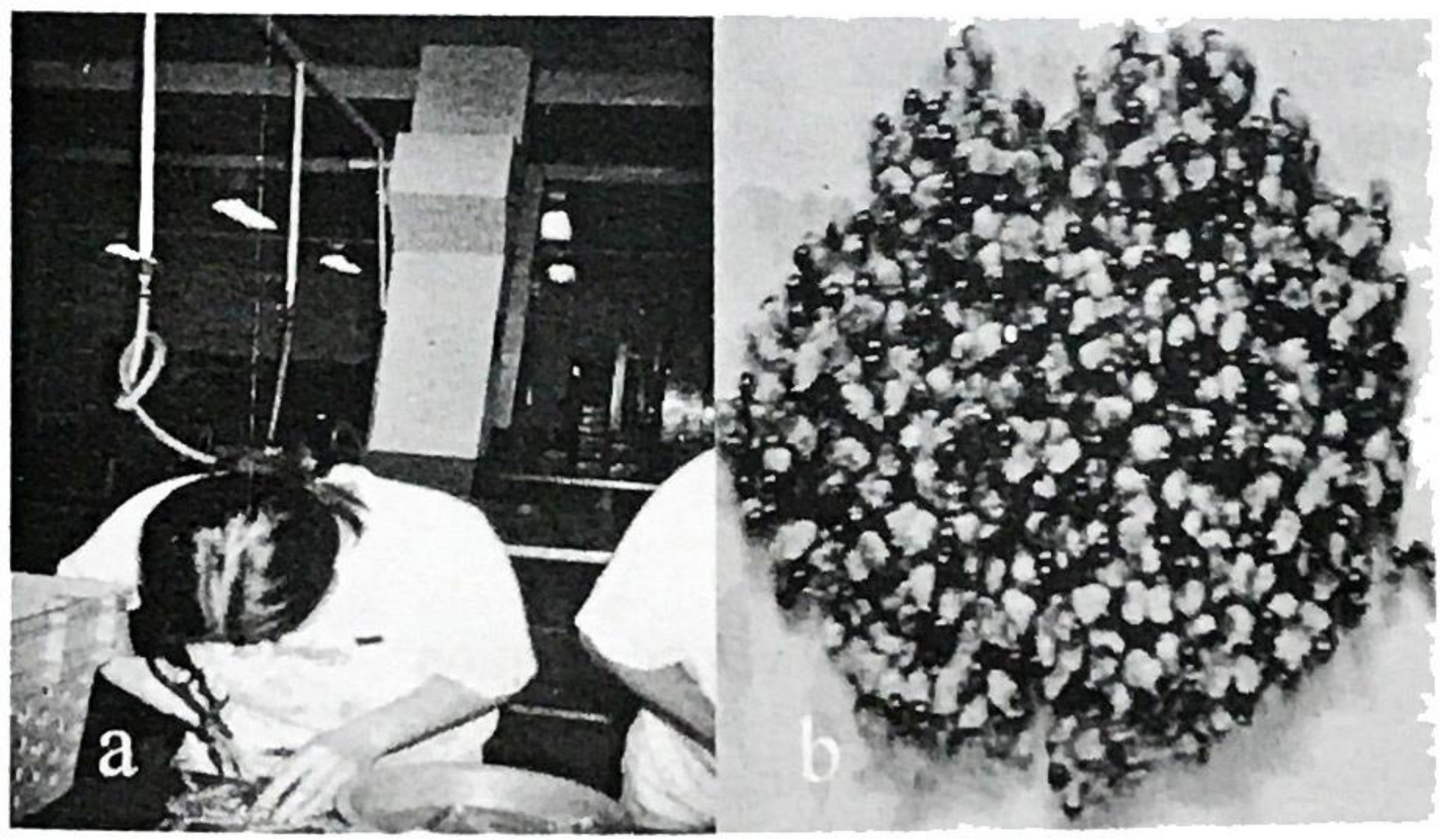

Figure 2. Gathering of blue crab eyestalks from Catbalogan, Samar (A) and collected eyestalks of $P$. pelagicus (B) 
were evaporated to dryness under reduced pressure using a Rotary Evaporator (ROTAVAPOR).

Different concentrations of the extract were prepared through serial dilution. Aside from the $70 \%$ ethanol that served as control, streptomycin was used as known control for further comparison. Streptomycin was also diluted according to the preparation of the different concentrations.

\section{Determination of the eyestalk extract concentration}

The concentration of the total eyestalk extracts was measured to be $2440 \mathrm{mg} \mathrm{mL}^{-1}$. This was obtained from about $100 \mathrm{~g}$ of eyestalks that came from approximately 100 crabs. The concentration was determined by subtracting the weight of the volumetric flask of the ROTAVAPOR from the weight of the volumetric flask with the dried fraction inside as shown below:

(Weight of volumetric flask + dried residue of eyestalk extract) -(Weight of volumetric flask) $=$ Weight of the dried residue of the extract.

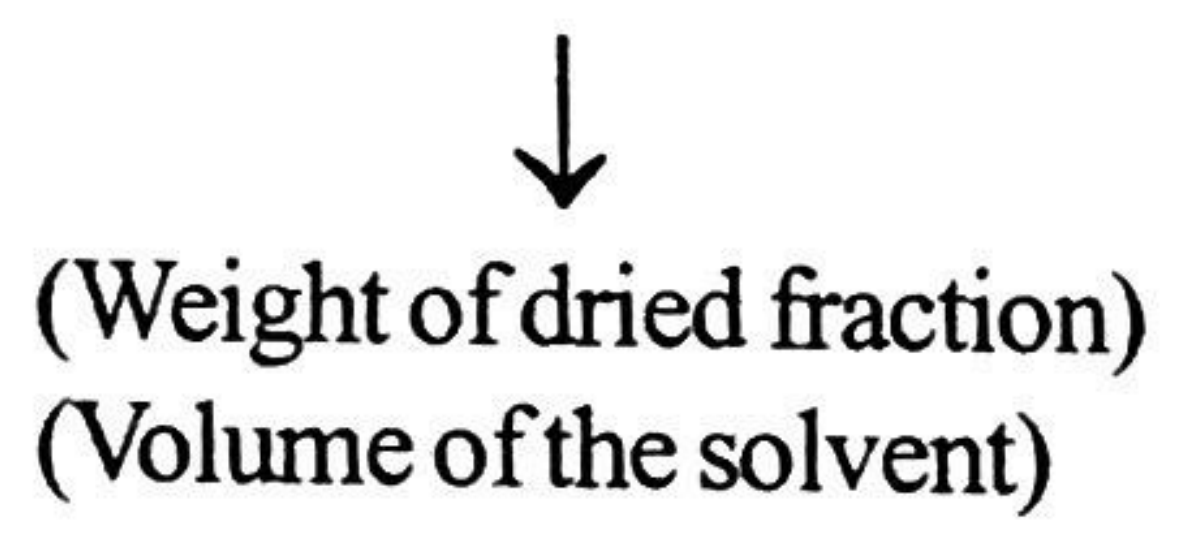

\section{Eyestalk Extract Concentration}

Weights were determined in grams and converted into milligrams to get concentration in $\mathrm{mg} \mathrm{mL}^{-1}$. The amount obtained was divided by the volume of the solvent used to reconstitute the extracts. Since not all the residues were dissolved by ethanol (polar), a non-polar solvent (chloroform) was used to dissolve all the residues left. The final concentration for the extract dissolved in chloroform was also taken by subtracting the weight of the residue dissolved in ethanol. Twelve concentrations were determined for both solvents.

The concentration obtained from the ethanol extract was $89 \mathrm{mg} \mathrm{mL}^{-1}$ Only the ethanolic extract was used for the final assay since the residue that was dissolved in chloroform showed no inhibitory effects even at its highest 
concentration against the two pathogens. Thirteen test tubes were prepared for the dilution of the different concentrations. Each test tube contained $1 \mathrm{~mL}$ of the solvent ( $70 \%$ ethanol) to serve as dilution blank. The tubes were labeled accordingly and $1 \mathrm{~mL}$ of the extract with the original concentration of $89 \mathrm{mg}$ $\mathrm{mL}^{-1}$ was added to the first test tube to get a concentration of $44.5 \mathrm{mg} \mathrm{mL}^{-1}$. The extract and solvent were mixed using a Vortex mixer. Serial dilution was employed in the preparation of the succeeding concentrations (Fig. 3). From the first tube, $1 \mathrm{~mL}$ was pipetted to the second, from the second to the third and so on. The same process was repeated until the lowest possible concentration of $0.01 \mathrm{mg} \mathrm{mL}^{-1}$ was reached.

The predicted minimum inhibitory concentration (MIC) was determined by computing the regression of the log of concentrations on the log of zones of inhibition for the eyestalk extracts and streptomycin. This is to distinguish the least possible inhibitory concentrations which showed antibacterial activity.

\section{Preparation of culture media}

Nutrient agar (NA) was used as culture medium for the test bacterial pathogens. The NA plates were made by dissolving 11.5 grams of nutrient agar in $500 \mathrm{~mL}$ of distilled water. This was melted and sterilized at $121^{\circ} \mathrm{C}$ for 15 minutes using an autoclave.

\section{Preliminary trials}

The efficacy of the extracts was first screened through preliminary trials. This was done to test different solvents and determine the appropriate procedure for the actual assay. Three organic solvents were tried - $70 \%$ ethanol, ethyl acetate and chloroform. However, ethyl acetate and chloroform did not show any inhibitory effect to both species so they were excluded as possible solvent. To determine the population density of pathogens, serial dilution was done. However, it was observed that the growth of the bacteria was not uniform although population density was the same. Hence, the top agar technique was chosen for the final assay. 


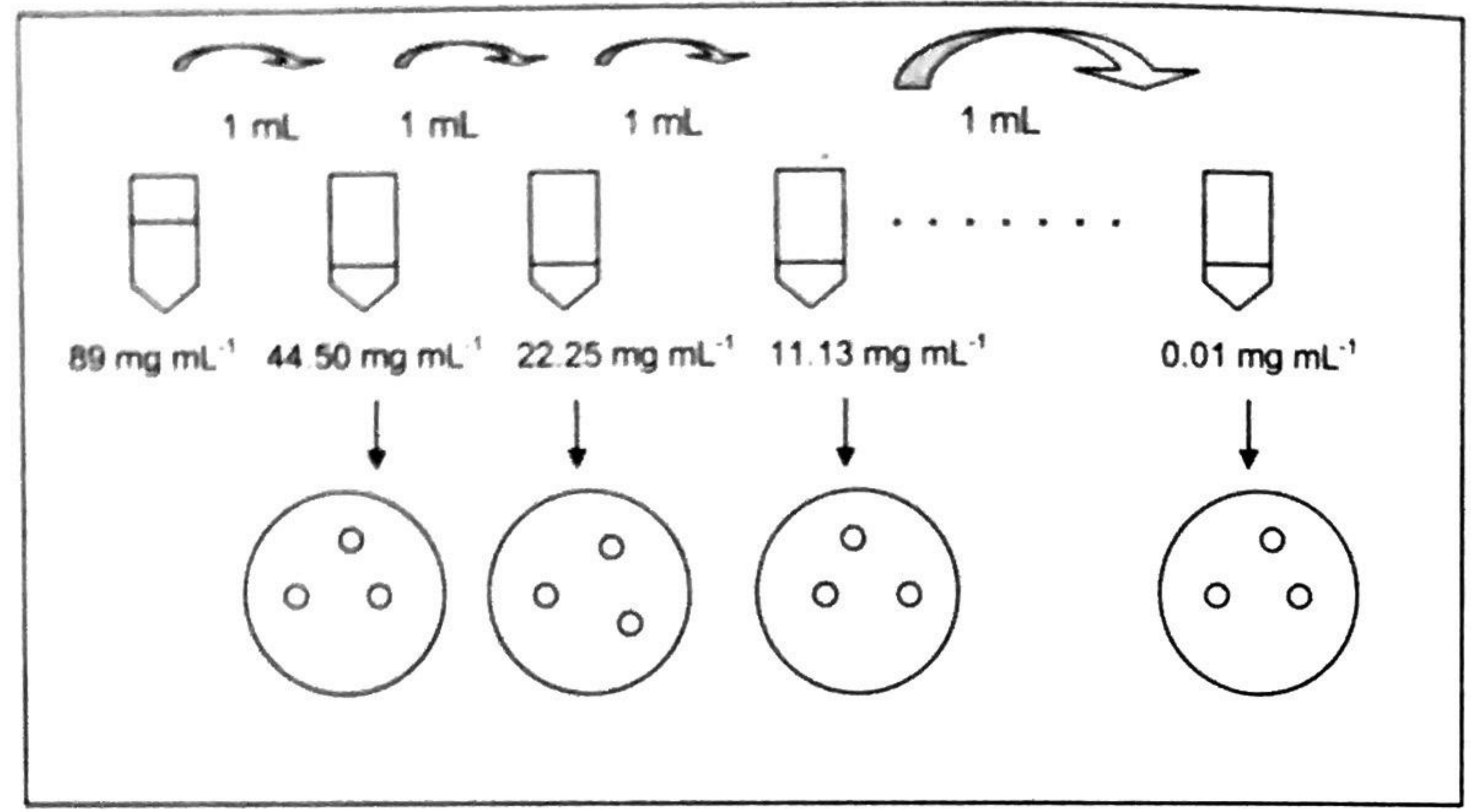

Figure 3. The serial dilution technique used to determine minimum inhibitory concentration (MIC).

Preparation of inoculum (Raymundo et al., 1981 as cited by Oclarit, 1987)

Top agar technique was used to ensure homogeneous distribution of inocula in the test plates. The ingredients used were 0.5 grams agar, 0.6 grams $\mathrm{NaCl}$ and $100 \mathrm{~mL}$ distilled water. The solution was transferred to an Erlenmeyer flask and sterilized at $121^{\circ} \mathrm{C}$ for 15 minutes in an autoclave. To each flask, $1 \mathrm{~mL}$ of test bacterium was inoculated and shaken. Observing aseptic procedures, $2.5 \mathrm{~mL}$ of inoculated top agar was dispensed to petri dishes containing previously plated NA using a $5000 \mathrm{~L}$ pipette.

\section{Test organisms}

The test organisms used were $P$. carotovorum subsp. carotovorum and $R$. solanacearum. The said organisms were obtained from cultured populations from the Department of Pest Management. To have enough cultures, these were again subcultured in NA slants. Some were inoculated in 
nutrient broth (NB) stocked in Eppendorf tubes with glycerol and placed in a freezer. This was done for long-term availability of cultures.

\section{Filter paper discs}

Filter paper discs of $6 \mathrm{~mm}$ diameter were obtained by punching holes on No. 1 Whatman filter paper. These were autoclaved at $121^{\circ} \mathrm{C}$ for 15 minutes to guarantee absence of contamination.

\section{Determination of bacterial population}

The population of the test pathogens was determined by serial dilution. Nine test tubes each containing $9 \mathrm{~mL}$ saline solution (dilution blank) were set up. These were labeled correspondingly from $10^{-1}$ to $10^{-9}$. From the stock culture, $1 \mathrm{~mL}$ of the test species was transferred into the top agar solution. Thorough mixing was done to ensure even distribution of bacteria, then $1 \mathrm{~mL}$ from the top agar solution with the test bacteria was added to the first dilution blank (first test tube) to make a $10^{-1}$ dilution. From the first test tube $\left(10^{-1}\right), 1$ $\mathrm{mL}$ was drawn using a $1000 \mu \mathrm{L}$ pipette and added to the second test tube. The same process was repeated until the last dilution blank was reached (109 ). In every addition of inoculum, thorough mixing was done. The first 4 dilution blanks $\left(10^{-1}, 10^{-2}, 10^{-3}\right.$ and $\left.10^{-4}\right)$ were used for the colony counts. From each dilution, five $1-\mathrm{mL}$ samples were plated. The average bacterial colony count of the 5 plates was used for the calculation of colony forming units (cfu). To calculate the probable number of bacteria in the original sample, the average bacterial colony count of the 5 trials for the $10^{-4}$ dilution was multiplied by the reciprocal of the dilution and of the volume used. Only plates with colonies ranging from $30-300$ were considered. The result gave the estimated number of bacteria in terms of $\mathrm{cfu}$. The average $\mathrm{cfu}$ obtained was multiplied by $2.5 \mathrm{~mL}$ for the estimation of the amount of bacteria in the top agar inoculum pipetted to each NA plate.

\section{Actual assay (Raymundo et al., 1981 as cited by Oclarit, 1987)}

The two assay species were examined one after the other. Aseptic conditions were ensured by disinfecting the working area with alcohol and 
passing all the materials needed over a flame. For every $100 \mathrm{~mL}$ of top agar, $1 \mathrm{~mL}$ of bacterial suspension was added after which thorough mixing was done to get an even distribution of the inoculum.

To the prepared agar plates, the seeded top agar solutions were pipetted at equal amounts of $2.5 \mathrm{~mL}$ per plate with a population of approximately 5.20 $\times 10^{6}-5.95 \times 10^{6}$ of $P$. carotovorum (mean of $5.58 \times 10^{6}$ ) and $4.63 \times 10^{6}$ $-5.70 \times 10^{6}$ for $R$. solanacearum (mean of $5.20 \times 10^{6}$ ). The inocula were spread by slight rotation of the plate and each plate was labeled with the corresponding concentration and bacterial pathogen used. The efficacy of the extract against the bacterial pathogens was tested by using blank sterile filter paper discs impregnated with $15 \mathrm{~L}$ of eyestalk extracts. The filter paper discs were set aside for the solvent to evaporate. From the trial set-up, it was observed that zones of inhibition were small and that one plate can accommodate 3 filter paper discs. Hence, three filter paper discs were placed in each properly labeled plate. Five replicates were prepared for each concentration of the extract and the known control for each pathogen. The degree of antagonism was determined at 24, 48 and 72 hours after inoculation by examining and measuring the zone of inhibition. However, the zone of inhibition apparently declined as the time of incubation increased. Hence, only the data after $24 \mathrm{hrs}$ of incubation was used. This was considered as the period of maximum inhibition after incubation. With the use of an ordinary plastic ruler, the diameters of the zones of inhibition were measured in millimeters $(\mathrm{mm})$.

Control treatments for both pathogens consisted of filter paper discs impregnated with $70 \%$ ethanol and streptomycin at the different concentrations.

\section{Experimental design}

The screening for each assay organism was arranged in a completely randomized design (CRD). The treatments were the 13 different extract concentrations including the ethanol control with five replicate cultures per treatment. The set-up for the streptomycin with the same concentrations and number of replicates was done under the same aseptic conditions as the extracts but this was conducted 2 weeks after extract assay which was done in December 2003 to January 2004 due to the limited number of petri plates available. However, data on the prevailing temperature during the conduct of 
the experiment was obtained from the Philippine Atmospheric, Geophysical and Astronomical Services Administration (PAGASA), LSU Station. Data obtained from the experiment was analyzed using one-way ANOVA. Treatment means were compared using Duncan's Multiple Range Test (DMRT).

\section{RESULTS AND DISCUSSION}

\section{Antibacterial effect on species}

Results of the screening show that extracts from blue crab eyestalks have antibacterial activity at bacterial populations of $4.63 \times 10^{6}-5.70 \times 10^{6}$ (R. solanacearum) and $5.20 \times 10^{6}-5.95 \times 10^{6}(P$. carotovorum $)$ since distinct zones of inhibition around the filter paper discs that were impregnated with the different concentrations of the extract were noted (Fig. 4). The zones of inhibition of the eyestalk extract, however, were much smaller than those of streptomycin (Fig. 5). This could be due to low concentrations of active substance in the crude extract. The filter paper discs were $6 \mathrm{~mm}$ in diameter and the highest inhibition attained by the extract was about $15 \mathrm{~mm}$ diameter that was about more than half the diameter of the filter paper discs.

Among the two pathogens initially tested with eyestalk extracts, $P$. carotovorum was inhibited more by the extract with a mean of $12 \mathrm{~mm}$ compared to $R$. solanacearum $(10.4 \mathrm{~mm})$. This was also true with the effect of streptomycin where it had greater zones of inhibition for the former species. The lower inhibition observed in $R$. solanacearum indicates that the extract has lesser inhibitory effect on the species. Moreover, it appears that antibacterial activity of the extract on $P$. carotovorum and $R$. solanacearum is lesser that that of streptomycin although direct comparison is not possible since crude eyestalk extracts and streptomycin assays were not done simultaneously.

\section{Effect of concentration on antibacterial activity}

The effect of concentration of crude eyestalk extracts and streptomycin on the test organisms are all highly significant $(\mathrm{p}=0.003)$. Table 1 shows a comparison of zones of inhibition of the eyestalk extracts on $R$. solanacearum 
Table 1. Mean diameter $(\mathrm{mm})$ of zones of inhibition in R. solanacearum $\left(4.63 \times 10^{6}-5.70\right.$ $\left.\times 10^{6}\right)$ and $P$. carotovorum $\left(5.20 \times 10^{6}-5.95 \times 10^{6}\right)$ treated with different concentrations of eyestalk extracts ${ }^{1}$

Concentrations ( $\mathrm{mg} \mathrm{mL}^{-1}$ )
Diameter of Zones of Inhibition (mm)

R. solanacearum

$10.40 \mathrm{~A}$

$9.80 \mathrm{AB}$

$9.60 \mathrm{~B}$

$8.60 \mathrm{C}$

$0.00 \mathrm{D}$

$0.00 \mathrm{D}$

$0.00 \mathrm{D}$

$0.00 \mathrm{D}$

$0.00 \mathrm{D}$

$0.00 \mathrm{D}$

$0.00 \mathrm{D}$

$0.00 \mathrm{D}$

$0.00 \mathrm{D}$
P. carotovorum
$12.00 \mathrm{~A}$
$11.80 \mathrm{~B}$
$10.00 \mathrm{C}$
$9.60 \mathrm{C}$
$9.40 \mathrm{C}$
$7.80 \mathrm{D}$
$0.00 \mathrm{E}$
$0.00 \mathrm{E}$
$0.00 \mathrm{E}$
$0.00 \mathrm{E}$
$0.00 \mathrm{E}$
$0.00 \mathrm{E}$
$0.00 \mathrm{E}$

\footnotetext{
${ }^{1}$ Means in a column followed by the same letter are not significantly different at $5 \%$ level, DMRT

** Minimum inhibitory concentrations (MIC)
}

and $P$. carotovorum. Maximum inhibition of the eyestalk extract on $R$. solanacearum $(10.4 \mathrm{~mm})$ and $P$. carotovorum $(12 \mathrm{~mm})$ was noted at the highest concentration of $44.5 \mathrm{mg} \mathrm{mL}^{-1}$. At an extract concentration of 2.78 $\mathrm{mg} \mathrm{mL}^{-1}$ and below, no antibacterial activity was observed on $R$. solanacearum. For $P$. carotovorum, antibacterial activity was still observed at this concentration until it reached $0.70 \mathrm{mg} \mathrm{mL}^{-1}$ where no more inhibition was observed. This suggests that at concentrations $=2.78 \mathrm{mg} \mathrm{mL}^{-1}$, blue crab eyestalk extracts could possibly be used as a control agent for this pathogen at bacterial populations of $4.63 \times 10^{6}-5.70 \times 10^{6}$. Concentrations $=1.39 \mathrm{mg}$ mL-1 could be effective against $P$. carotovorum at bacterial populations of $5.20 \times 10^{6}-5.95 \times 10^{6}$. As shown in the table, $P$. carotovorum demonstrated more sensitivity to the inhibitory hormones found in blue crab eyestalks since it is inhibited by at least $1.39 \mathrm{mg} \mathrm{mL}^{-1}$ while $R$. solanacearum appears to be a more resistant species needing higher dosage of eyestalk extract to be 


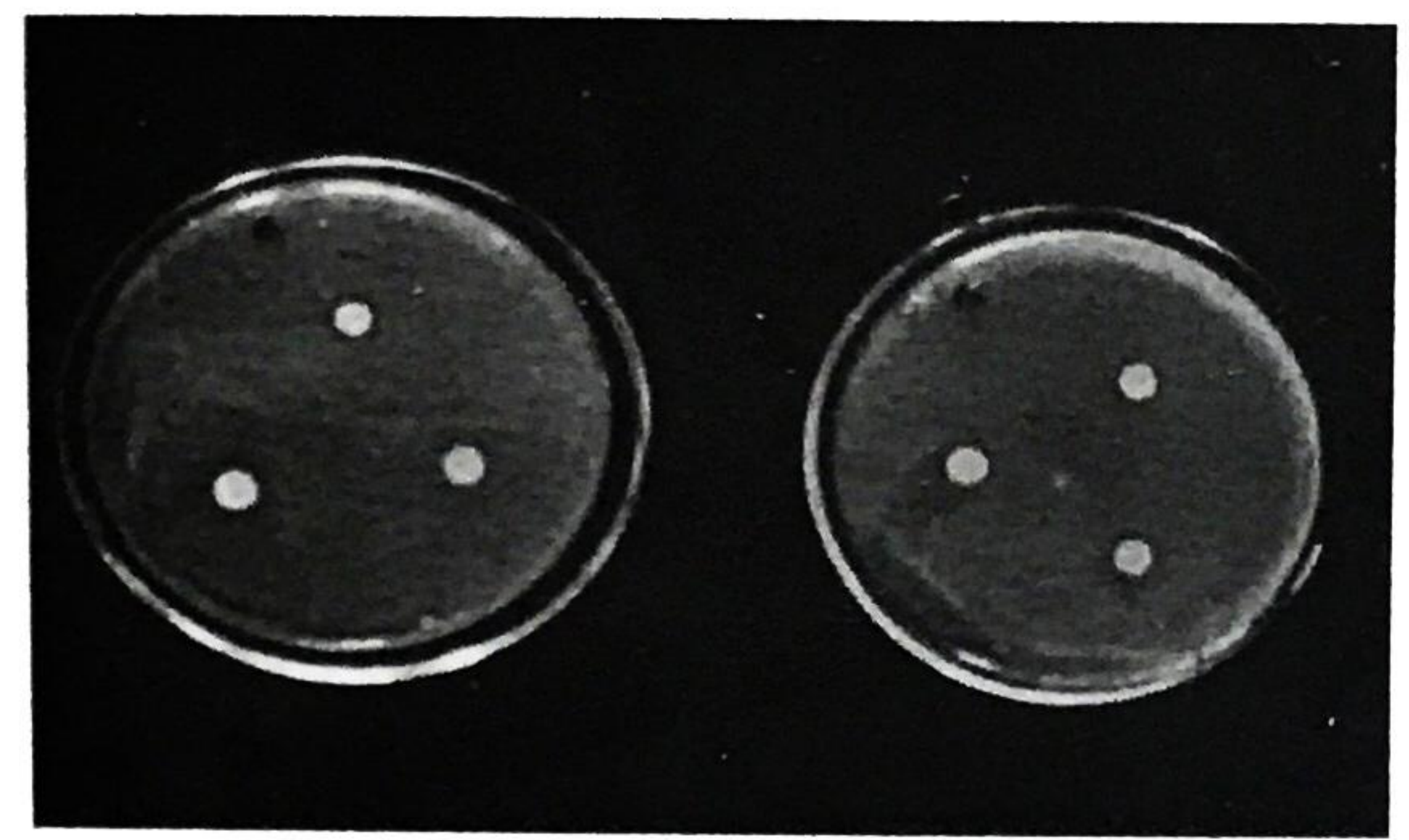

Figure 4. Zones of inhibition of Ralstonia solanacearum (A) at a population of $4.63 \mathrm{x}$ $10^{6}-5.70 \times 10^{6}$ and Pectobacterium carotovorum (B) at a population of 5.20 $\times 10^{6}-5.95 \times 10^{6}$ treated with $44.5 \mathrm{mg} \mathrm{mL}^{-1}$ crude eyestalk extracts

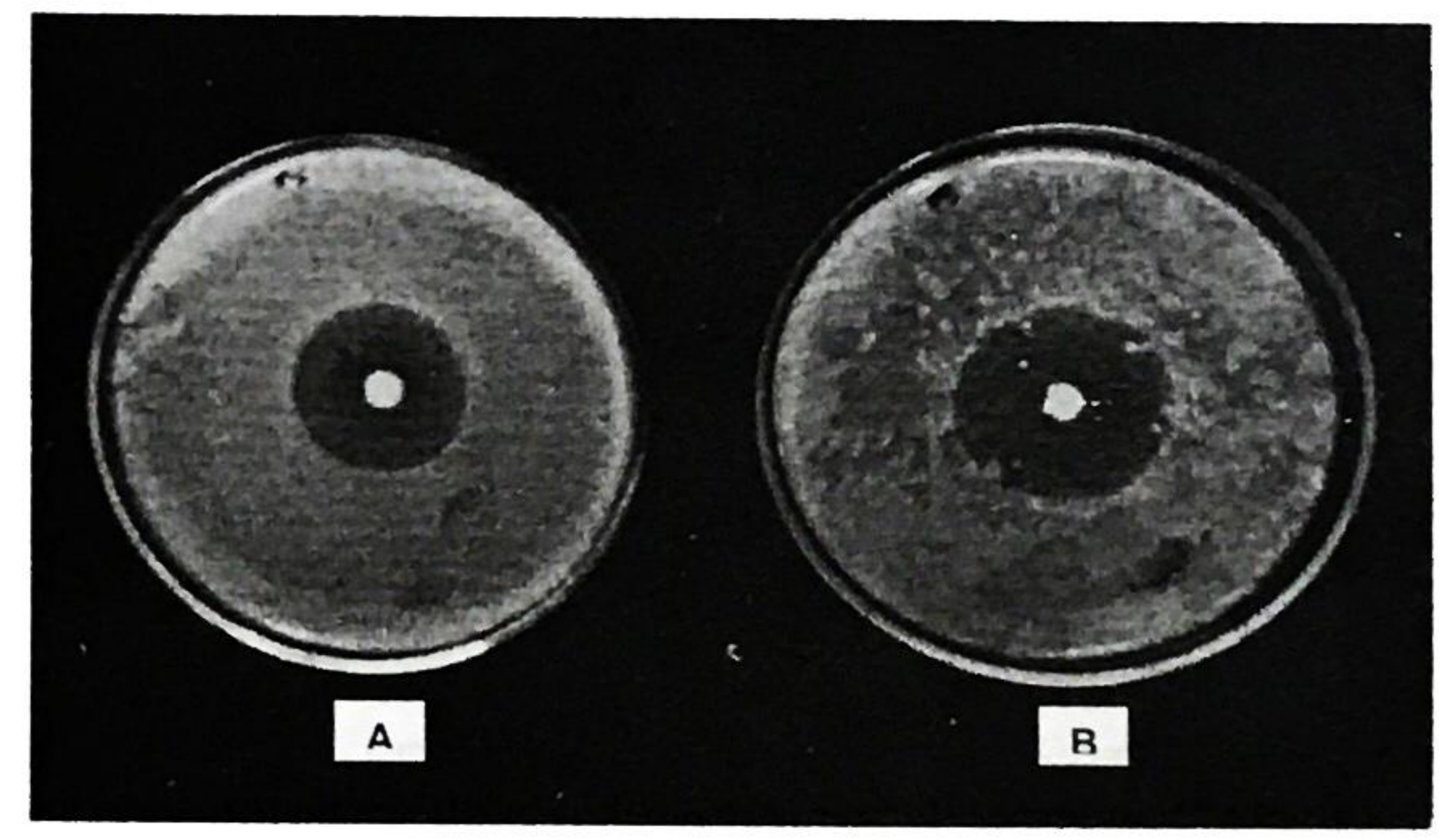

Figure 5. Zones of inhibition of Ralstonia solanacearum (A) at a population of $4.63 \mathrm{x}$ $10^{6}-5.70 \times 10^{6}$ and Pectobacterium carotovorum (B) at a population of $5.20 \mathrm{x}$ $10^{6}-5.95 \times 10^{6}$ treated with $22.25 \mathrm{mg} \mathrm{mL}^{-1}$ streptomycin. 


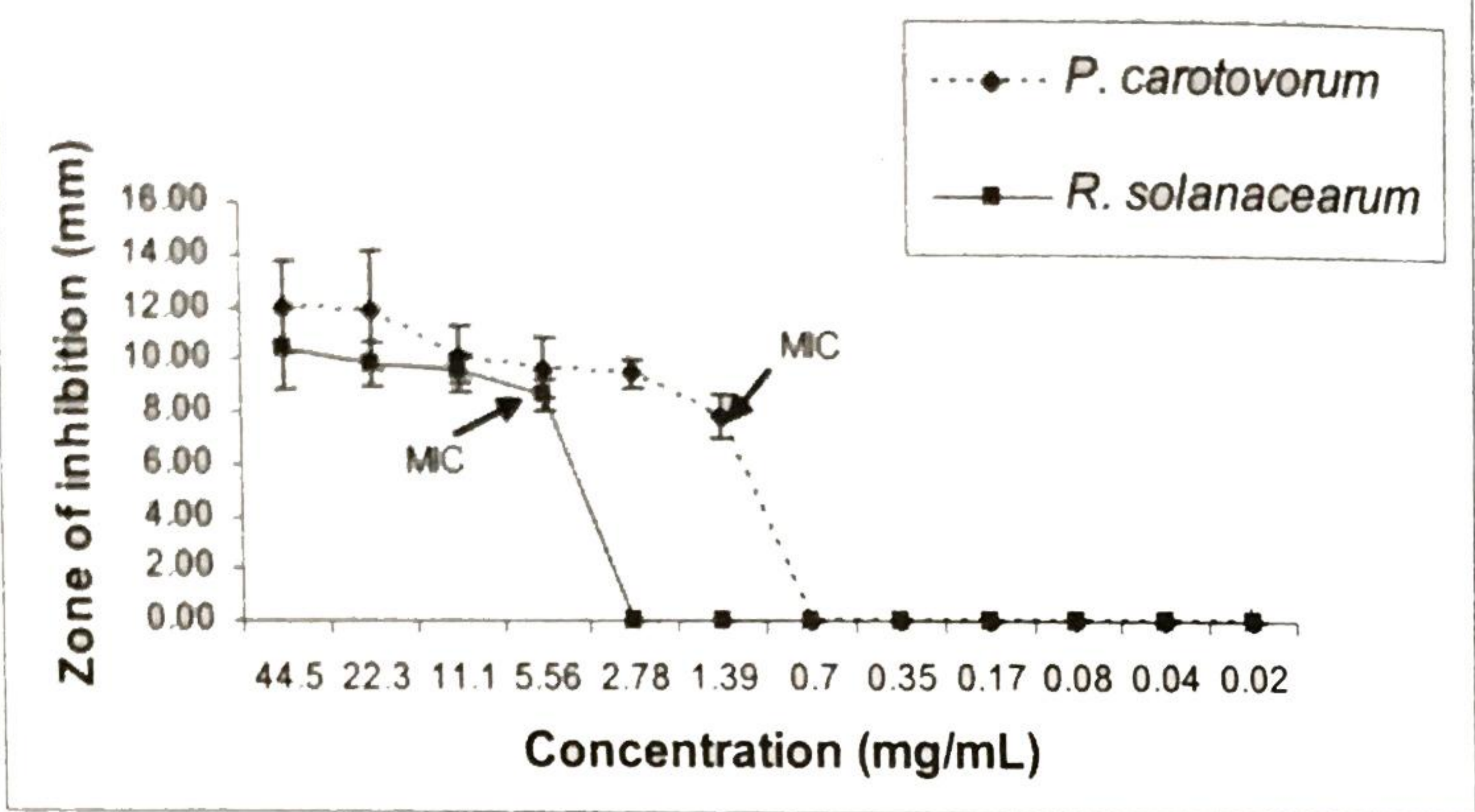

Figure 6. Zones of inhibition of two bacterial pathogens treated with different concentrations of $P$. pelagicus eyestalk extracts.

inhibited.

The minimum inhibitory concentrations (MIC) of the eyestalk extracts on the two pathogens were also different. For $R$. solanacearum, minimum extract inhibition was noted at $5.56 \mathrm{mg} \mathrm{mL}^{-1}$ (Fig. 6). However, the predicted MIC was lower at $3.62 \mathrm{mg} \mathrm{mL}^{-1}$ (Fig. 7). For P. carotovorum, the MIC was at $1.39 \mathrm{mg} \mathrm{mL}^{-1}$, with a predicted value of $1.58 \mathrm{mg} \mathrm{mL}^{-1}$ of the eyestalk extract. This means that it needed lesser concentration of the extract to be inhibited as compared with $R$. solanacearum.

Comparative inhibition of $R$. solanacearum and $P$. carotovorum by streptomycin at different concentrations is reflected in Table 2. Streptomycin had its maximum inhibition at the same concentration as the eyestalk extract but with a significantly larger zone of inhibition for both pathogens $(R$. solanacearum with $34.2 \mathrm{~mm}$ and $P$. carotovorum with $39.2 \mathrm{~mm}$ ).

The known antibiotic streptomycin had its MIC for $R$. solanacearum at $0.04 \mathrm{mg} \mathrm{mL}^{-1}\left(0.03 \mathrm{mg} \mathrm{mL}^{-1}\right.$ for the predicted value). No antibacterial activity was observed at $0.02 \mathrm{mg} \mathrm{mL}^{-1}$ of streptomycin. For $P$. carotovorum, MIC was at $0.02 \mathrm{mg} \mathrm{mL}^{-1}$ with a computed value of $0.01 \mathrm{mg} \mathrm{mL}^{-1}$ (Fig. 8). It is possible that streptomycin can still inhibit $P$. carotovorum at concentrations 
Table 2. Mean diameter $(\mathrm{mm})$ of zones of inhibition in $R$. solanacearum $\left(4.63 \times 10^{6}-5.70\right.$ $\left.\times 10^{6}\right)$ and $P$. carotovorum $\left(5.20 \times 10^{6}-5.95 \times 10^{6}\right)$ treated with different concentrations of streptomycin.'

\begin{tabular}{lll}
$\begin{array}{l}\text { Concentrations } \\
\left(\mathrm{mg} \mathrm{mL}^{-1}\right)\end{array}$ & \multicolumn{2}{c}{$\begin{array}{c}\text { Diameter of Zones of Inhibition }(\mathrm{mm}) \\
\text { P. carotovorum }\end{array}$} \\
\hline 44.50 & $34.20 \mathrm{~A}$ & $39.20 \mathrm{~A}$ \\
22.25 & $30.20 \mathrm{~B}$ & $34.60 \mathrm{~B}$ \\
11.13 & $27.00 \mathrm{C}$ & $30.00 \mathrm{C}$ \\
5.56 & $25.00 \mathrm{D}$ & $29.40 \mathrm{C}$ \\
2.78 & $24.60 \mathrm{D}$ & $27.60 \mathrm{D}$ \\
1.39 & $22.20 \mathrm{E}$ & $25.80 \mathrm{E}$ \\
0.70 & $19.80 \mathrm{~F}$ & $24.80 \mathrm{E}$ \\
0.35 & $18.80 \mathrm{~F}$ & $23.20 \mathrm{~F}$ \\
0.17 & $13.80 \mathrm{G}$ & $16.40 \mathrm{G}$ \\
0.08 & $13.40 \mathrm{G}$ & $11.80 \mathrm{H}$ \\
$0.04^{* *}$ & $10.40 \mathrm{H}$ & $9.80 \mathrm{I}$ \\
$0.02^{* *}$ & $0.00 \mathrm{I}$ & $9.00 \mathrm{I}$
\end{tabular}

' Means in a column followed by the same letter are not significantly different at $5 \%$ level, DMRT.

** Minimum inhibitory concentrations (MIC)

lower than $0.02 \mathrm{mg} \mathrm{mL}^{-1}$ which was not covered in the present study. These lower MICs of the extract and streptomycin on $P$. carotovorum again indicate that it is a less resistant bacterium than $R$. solanacearum.

Interaction effects of the eyestalk extracts and streptomycin between species and concentrations were not statistically analyzed since streptomycin assay was done on another date. However, it is obvious that $P$. carotovorum was more susceptible to inhibition by the extract as exhibited by greater zones of inhibition and a lower MIC $\left(1.39 \mathrm{mg} \mathrm{mL}^{-1}\right)$ as compared to $R$. solanacearum $\left(5.56 \mathrm{mg} \mathrm{mL}^{-1}\right)$. This also indicates that $R$. solanacearum required a higher dosage of the extract to produce similar degree of inhibition as $P$. carotovorum.

Results of the study thus demonstrate and document growth inhibitory effects of blue crab crustacean eyestalk extracts on the bacterial pathogens $R$. solanacearum and $P$. carotovorum at population densities of $4.63 \times 10^{6}$ $5.70 \times 10^{6}$ for the former and $5.20 \times 10^{6}-5.95 \times 10^{6}$ for the latter. Although 


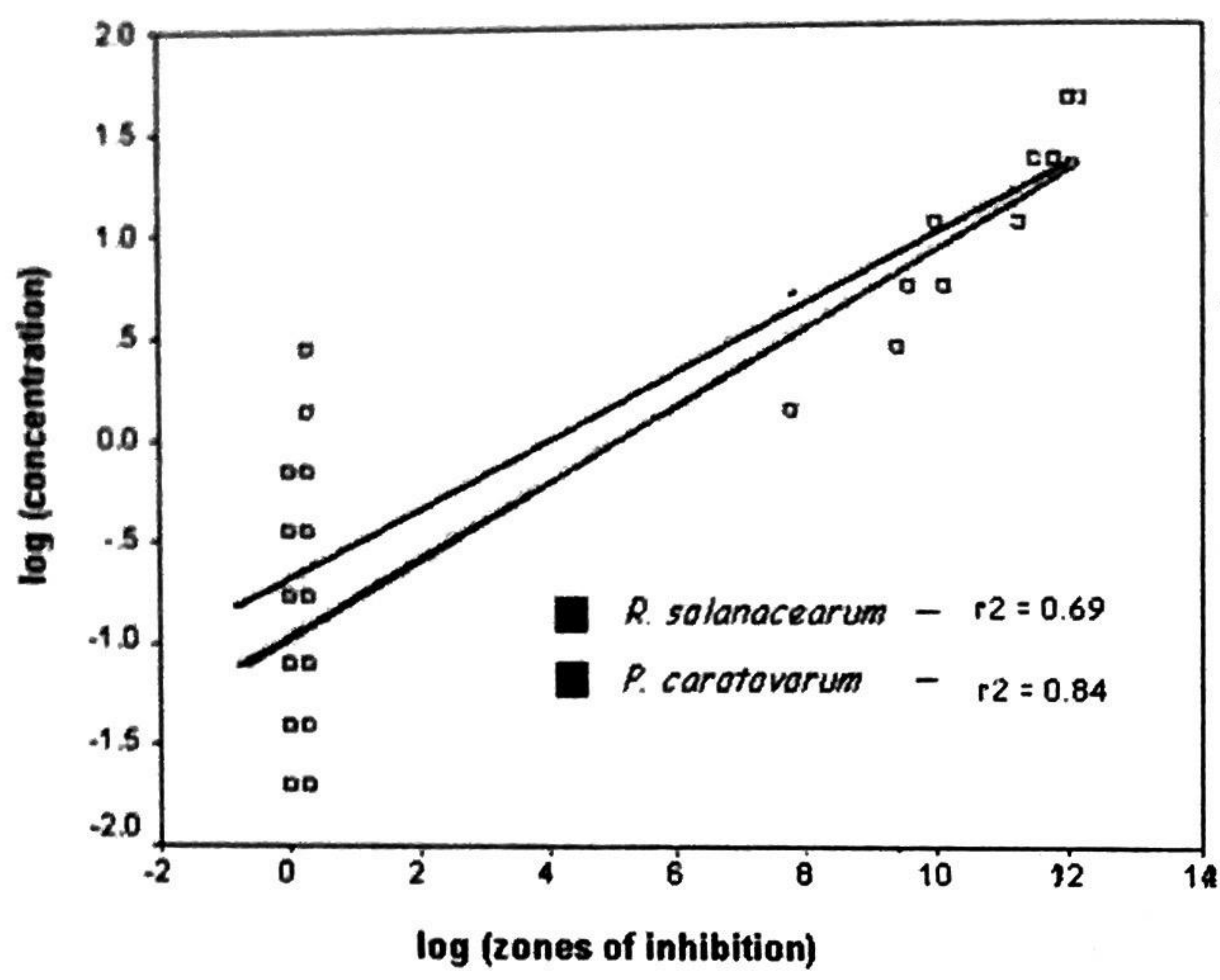
Predicted MIC of R. solanacearum.
$\log \operatorname{con}=-0.6302+0.1917 x$
$=-0.6302+(1.189)$
$=3.621$.

Where: $x=6.2 \mathrm{~mm}(0$ inhibition $)$

Predicted MIC of $P$. carotovorum

$\log$ con $=-0.9614+0.1871 \mathrm{x}$

$=-0.9614+(1.160)$

$=1.58$

Where: $x=6.2 \mathrm{~mm}(\sim$ inhibition $)$

Figure 7. Predicted minimum inhibitory concentration (MIC) from the regression of concentration on the zones of inhibition of $R$. solanacearum and $P$. carotovorum for eyestalk extracts where $6.2 \mathrm{~mm}$ is the diameter of the filter paper discs.

less effective than streptomycin, blue crab eyestalk extracts could be used as a possible cheaper alternative for the control of a wide range of diseases caused by $P$. carotovorum (bacterial soft rots, blackleg; Rich, 1983) and $R$. solanacearum (bacterial wilt, brown rot; Rich, 1983). However, its effect on higher populations of the said pathogens need to be determined. Streptomycin is commonly known to control these pathogens (Garrett as edited by RhodesRoberts and Skinner, 1982). Infected areas were treated with this antibiotic since it can reduce bacterial infection. However, Bonde and Malcolenson (1956) as cited by Rich (1983) stated that this particular antibiotic would also increase fusarium dry rot. In 1960, Rich et al. concluded that it did more harm than good.

The mechanism by which blue crab eyestalks could have inhibited growth in these bacterial pathogens possibly involve inhibition of incorporation of needed precursors into macromolecules presumably due to depression of RNA and protein synthesis. A similar mechanism had been invoked by Chang (1989) and others (Kleinholz, 1976; Bliss, 1966; Skinner, 1984) to explain molting 


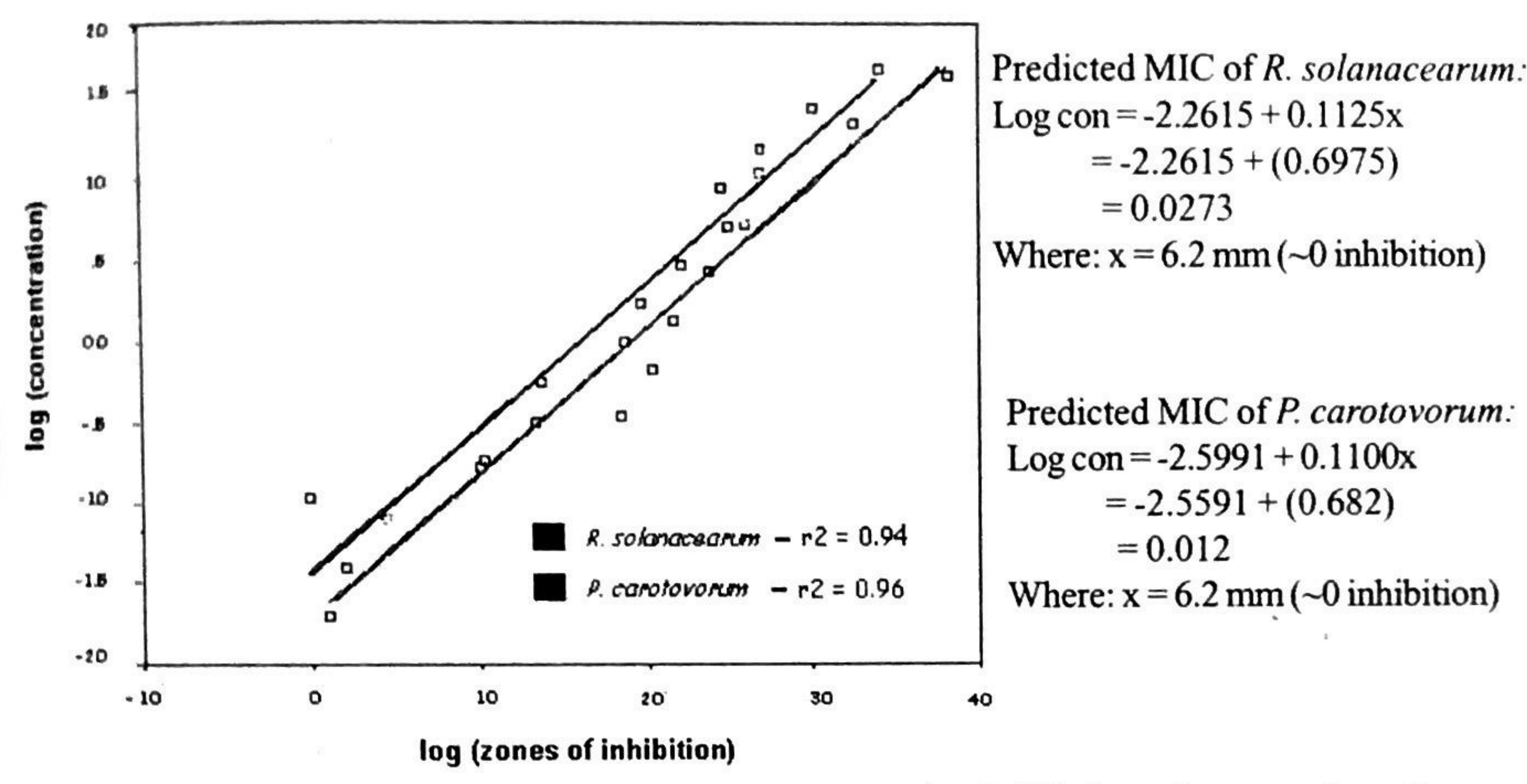

Figure 8. Predicted minimum inhibitory concentration (MIC) from the regression of concentration on the zones of inhibition of $R$. solanacearum (A) and $P$. carotovorum (B) for streptomycin where $6.2 \mathrm{~mm}$ is the diameter of the filter paper discs.

and growth inhibition by neurosecretory hormones in crustacean eyestalks, removal of which has been found to accelerate molting, enhance growth and gonadal development (Germano, 1994). The virulence of bacteria causing soft rots (such as $P$. carotovorum) and bacterial wilts ( $R$. solanacearum) has been correlated with their production of enzymes capable of degrading cell wall components (Bateman and Miller, 1966). Since most enzymes are proteins, possible depression of RNA and protein synthesis by eyestalk factors might also inhibit the infective capacity of the bacterial pathogens studied once infection has begun (However, this remains to be investigated). This suggests that blue crab eyestalk extracts can be used both as preventive and control measures against $P$. carotovorum and $R$. solanacearum. The latter pathogen has broader host range (Kelman, 1953) and has been classified into 3 different races based on their infection to the different hosts (Buddenhagen et al., 1962). According to Gillings and Fahy (1994), R. solanacearum is a complex and heterogeneous species. Because of its complexity, control of such pathogen has been continually studied, this species being considered as among the most important destructive pathogens. Breeding for disease resistance has not been 
very successful because of the extensive variability of bacterial strains and the interaction of a myriad of biotic and abiotic factors (Javier as edited by Hayward et al., 1994). This could explain its seeming resistance to the eyestalk extracts as shown by a higher MIC.

It is possible that the efficacy of blue crab eyestalk extracts as antibacterial agents may be higher than obtained in the present study. This inference is made because the extracts were obtained from eyestalks of crabs of different sizes and at different stages in the molt and reproductive cycle, which could have diluted the concentration of active inhibitory substances. It is necessary to refine future investigations by choosing eyestalks from crabs that are at the intermolt stage, i.e, not soft shelled and have no pinkish or reddish lines on penultimate and ultimate swimming paddles and on abdomen (Millikin and Williams, 1984). Furthermore, since molting and mating occurs at about full or new moon, sampling should not be done at this time since molting-inhibiting and gonad-inhibiting hormones are expected to have low concentrations at this time.

\section{CONCLUSIONS AND RECOMMENDATIONS}

Based on the results of the screening, blue crab eyestalk extracts may thus be recommended as a possible preventive and/or control agent against the bacterial pathogens $P$. carotovorum and $R$. solanacearum. Compared to streptomycin, use of eyestalk extracts may be more cost effective and may also render a waste product in blue crab processing useful and even profitable. However, further verification should be conducted to determine its effect at higher populations of the pathogens. Further studies are also needed to maximize antibacterial effects through a more refined eyestalk sampling regime and use of other solvents such as acetone which is also a good chlorophyll extractant. Field testing on the application of crude and dried eyestalk extracts for possible prevention and/or control of diseases caused by the two bacterial species also need to be done to establish protocols for their effective use. Further investigation to determine and possibly purify the major inhibiting compounds found in the eyestalk should be done using Thin Layer 
Chromatography (TLC) or other suitable methods like high performance liquid chromatography (HPLC). Finally, testing of grow th inhibitory effects of blue crab eyestalk extracts on fungi and other eucaryotic cells may also yield encouraging results.

\section{ACKNOWLEDGEMENT}

The authors wish to acknowledge Dr. Jose M. Oclarit and Prof. Jesusito L. Lim for their comments and criticisms which significantly improved the manuscript. Likewise, to the Managers of Orient Cold Storage Incorporated (OCSI) and Phillips Seafood Inc. at Catbalogan, Samar, and to Dr. Latip Abdurahman who facilitated contact with the manager of the OCSI factory.

\section{LITERATURECITED}

BATEMAN, D. F. and R. L. MILLAR. 1966. Pectic enzymes and tissue degradation. Ann. Rev. of Phytopath. 4:119-146.

BLISS, D. E. 1966. Neurosecretion on invertebrates other than insects. Part IV. Introduction: Relation between reproduction and growth in decapod crustaceans. Amer. Zool. 6:231-233.

BUDDENHAGEN, I. W. and A. KELMAN. 1964. Biological and physiological aspects of bacterial wilt caused by Pseudomonas solanacearum. Ann. Rev. of Phytopath. 2: 203-30.

CHANG E. S. 1989. Endocrine regulation of molting in Crustacea. Rev. Aquatic Sci. 1: 131-157.

GERMANO, B. P. 1994. Effects of unilateral eyestalk ablation on growth in juvenile blue crabs Portunus pelagicus L. (Crustacea: Decapoda: Portunidae). Asian Fisheries Science 7:19-28.

GILLINGS M. R. and P. FAHY. 1994. Genomic fingerprinting: Towards a unified view of the Pseudomonas solanacearum species complex. NSW Agriculture, Biological and Chemical Research Institute. In: Bacterial Wilt: The Disease and its Causative Agent, Pseudomonas solanacearum (Hartman, G.L. \& Hayward, A. C., eds.). CAB International. 95-112 pp.

HAYWARD A. C. and G. L. HARTMAN. 1994. Bacterial Wilt: The Disease and its 
Causative Agent. Pseudomonas solanacearum. CAB International. pp xi.

KELMAN, A. 1953. The bacterial wilt caused by Pseudomonas solanacearum. Technical Bulletin 99, North Carolina Agricultural Experiment Station, Raleigh, USA. pp 194.

KLEINHOLZ, L. H. 1976. Crustacean neurosecretory hormones and physiological specificity. Amer. Zool. 16: 151-166.

MILLIKIN, M. R. and A. B. WILLIAMS. 1984. Synopsis of biological data on the blue crab Callinectes sapidus. Rathbun. NOAA Technical Reports NMFS 1. FAO Fisheries Synopsis No. 138. 39 p.

OCLARIT, J. M. 1987. Studies on the Antimicrobial Activity of Some Philippine Marine Sponges. MS Thesis. University of the Philippines, Diliman, Q. C.

RAYMUNDO, A. K., F. ZULAYBAR, L. CRUZ and G. CORPUS. 1981. Antimicrobial activity of limited species of marine sponges in the Philippines. Annual Report of National Institute of Biotechnology and Applied Microbiology, Los Baños, Laguna.

RHODES-ROBERTS M. E. and F. A. SKINNER. 1982. Bacteria and Plants. The Society for Applied Bacteriology Symposium Series No. 10. Academic Press, New York. $117-127 \mathrm{pp}$.

RICH, A. E. 1983. Potato Diseases. Academic Press, New York. pp 4-15.

RICH, A. E., C.S. CAMPBELL, R.E. MULLARY, F.E. MANZER and P. T. BLOOD. 1960. The influence of various fungicides and antibiotics on cut seed potatoes. Am. Potato J. 37, 351pp.

SKINNER, D. M. 1984. Molting and regeneration. In: The Biology of Crustacea, Vol 9 (eds. D. E. Bliss and L. H. Mantel). Academic Press, New York. 43-146 pp. 